\title{
Synthesis of Ferrocene Based Organometallic Compounds \& Antimicrobial Activity
}

\author{
Gulam Farooq $\mathrm{M}^{1} \&$ Manohar V Lokhande ${ }^{2 *}$ \\ ${ }^{I}$ Department of Chemistry, Sir Sayyed College, Aurangabad-431001(Maharashtra-India) \\ ${ }^{I}$ Department of Chemistry, Shri Jagdish Prasad Jhabarmal Tibrewala University, Vidya Nagari, Jhunjhunu - \\ Churu Road, Chudela, Dist. Jhunjhunu -333001,(Rajasthan- India). \\ $2^{2 *}$ Department of Chemistry, Sathaye College, Mumbai-400057(Maharashtra-India)
}

\begin{abstract}
The synthesis, characterisation, spectral studies, antibacterial and fugal studies of some transition metal ions like $\mathrm{Mn}^{++}, \mathrm{Co}^{++}, \mathrm{Ni}^{++}, \mathrm{Cu}^{++}, \mathrm{Pd}^{++}$and $\mathrm{Pt}^{++}$complexes of ferrocene based Organometallic compounds have been reported. The coordinate bonding of nitrogen to the central metal atom which reduces the electron density in the both azomethine link and thus lower the $-H C=N$ - absorption. The elemental analysis data exhibit the formation of 1:1 [M: L] ratio with coordination number six in the all complexes. The complexes have with octahedral geometry and $D_{4} h$ symmetry. The ferrocene based organometallic compound shows a molecular ion peak at $\mathrm{m} / \mathrm{z} 482.4$ which is equal to theoretical molecular weight. The molar conductance value indicates that, they are non- electrolytic in nature. These complexes were tested with some bacteria and fungi.

Keywords: ferrocene based organometallic compounds, IR, Mass spectra, electronic spectra, Electron Spin Resonance and antimicrobial activity.
\end{abstract}

\section{Introduction:}

The fields of organometallic compounds have been fast developing on account of the wide variety of possible structures for the ligands depending upon the Aldehydes and amines. Organometallic compounds are considered as a very important class of ferrocene \&organic compounds, which have wide applications in many biological aspects [1-2]. Transition metal complexes of organometallic compounds are one of the most adaptable and thoroughly studied systems. These complexes have also applications in clinical and medicinal in addition to their important roles in catalysis and organic synthesis [3-7].Studies of a new kind of chemotherapeutic organometallic compounds were now attracting the attention of biochemists. Organometallic compounds metal complexes can now be considered a widely studied subject due to their industrial and biological applications [8-9]. Earlier work reported that some drugs showed increased activity when administered as metal complexes rather than as organic compounds [10]. Organometallic compounds derived from 3-ethoxy-2-hydroxybezaldehyde and 1,1'-diaminoferrocene and characterized them by various analytical methods IR, UV-VIS, ESR, mass spectra. The present aim of the work is to synthesized a new series of ferrocene based organometallic compounds from 3-ethoxy-2-hydroxybezaldehyde and 1,1'-diaminoferrocene a to prepare some transition metal complexes, characterize them and study of antibacterial and anti fungal activities

\section{Experimental}

2.1 Materials and methods: All reagents and chemicals were of analytical grade, used without any further purification. The ferrocene diamine compounds were obtained from Merck Ltd. All solvents were purified \& distilled by distillation before using.

2.2 Preparation of ferrocene based organometallic compounds and metal complexes: ferrocene based organometallic compounds prepared by mixing of $(0.05 \mathrm{M})$ methanoic solution of the 1,1'-Diaminoferrocene with $(0.02 \mathrm{M})$ ethanolic solution of 3-ethoxy-2-hydroxybenzaldehyde were reflux for five hours using water condenser at $80^{\circ} \mathrm{C}$. After complete refluxation, the solution were cooled at room temperature, keep in dark place for 24 hours, solid separates and dry at $70{ }^{\circ} \mathrm{C}$. The $0.02 \mathrm{M}$ Solution of $\mathrm{Mn}$ acetate, Co acetate , Ni acetate , $\mathrm{Cu}$ acetate, $\mathrm{PdCl}_{2}$ and $\mathrm{PtCl}_{2}$ salt solutions were prepared in double distilled water. The solutions of $0.04 \mathrm{~m}$ ferrocene based organometallic compounds were prepared in absolute alcohol. The $20 \mathrm{~cm}^{3}$ of $0.04 \mathrm{M}$ solution of ferrocene based organometallic compounds and $20 \mathrm{~cm}^{3}$ solution of metal acetate and chloride solutions were refluxed for 3 hours using water condenser, by using few drops of alcoholic ammonia solution. This solution will keep for 24 hours in dark place, the coloured solid residue formed and dried at $60^{\circ} \mathrm{C}$ in oven. The yields of complexes were obtained in range between $44-52 \%$.

Reaction:1,1'-Diaminoferrocene+3-ethoxy-2-hydroxybenzaldehyde $\rightarrow 2$-ethoxy-6-(\{2'-[(E)-(3-ethoxy-2hydroxy benzylidene)amino]-1,1'(ferrocene-2,4-dien-1-yl)-2-yl) carbonimidoyl) phenol 
2.3 Instrumental techniques: The elemental analyses were determined by using micro analytical technique. IR spectra were carried out by using $\mathrm{KBr}$ pellets by Perkin Elmer spectrophotometer. The electronic spectra were recorded using ethanol, DMSO and water as a solvent. Melting points of the ligand and decomposition temperature of complexes were determined in our laboratory.

\section{Result and Discussion:}

The physical and analytical data are listed in table No.1. The metal contains were estimated by volumetrically using EDTA, Pd(II) and Pt(II) metals estimated by AAS method . Iron metal estimated by gravimetrically [11]. All the complexes are soluble in DMSO and DMF. Melting point taken in open capillary and which is uncorrected. All the complexes are non-electrolytic in nature [12-13] and stable at room temperature.

3.1 IR Spectra: The IR spectral bands of ferrocene based organometallic compound and their complexes are given in table No.2. The IR spectra provide valuable information regarding the nature of functional group and its bonding where the group is present. The bonding mode of in the ferrocene based organometallic compound metal ion complexes. A band at $1690 \mathrm{~cm}^{-1}$ in ferrocene based organometallic compound is due to $>\mathrm{C}=\mathrm{N}$ vibration. The shifting of these groups at lower frequency in the range $1620-45 \mathrm{~cm}^{-1}$ in the metal complexes, when these values compared to ferrocene based organometallic compound. Hence it suggests that the bonding through metal ion with nitrogen atom of azomethine group [14]. The coordinate bonding of nitrogen to the central metal atom which reduces the electron density in the both azomethine link and thus lower the $-\mathrm{HC}=\mathrm{N}$ absorption[15]. A band at $3380 \mathrm{~cm}^{-1}$ is assigned to Ar-OH frequency in the spectrum of ferrocene based organometallic compound, but in the complexes both bands does not appears in the complexation, which means that involvement of both oxygen atom of hydroxyl group of Ar-OH group in bonding with metal ions [16-17].

New bands were observed in the metal ion complexes, but bands are not present in the spectrum of ferrocene based organometallic compound. The spectra of complexes in the range of $558-572 \mathrm{~cm}^{-1}$, corresponding to metal- nitrogen bonding [18-19] and 412-443 $\mathrm{cm}^{-1}$ corresponding to metal-oxygen bonding respectively[20]. The appearances of vM-N and vM-O vibrations support the involvement of $\mathrm{N}$ and $\mathrm{O}$ atoms in complexation with metal ions[21-22]. The $\mathrm{vC}-\mathrm{O}$ (Phenol) stretching frequency of ferrocene based organometallic compound have seen at $1365 \mathrm{~cm}^{-1}$ gets shifted to a lower frequency region in the complexes in the range of 1318-33, it indicates that bonding through phenolic-Oxygen. Therefore the infrared spectral data indicates that the coordination sites of the metal ions are $-\mathrm{HC}=\mathrm{N}$ and $\mathrm{Ar}-\mathrm{OH}$.

3.2 Electronic spectra: The electronic spectral data of the ferrocene based organometallic compound organometallic compounds and its complexes were recorded in DMF and Ethanol. $\left(0.001 \mathrm{Mole} / \mathrm{dm}^{3}\right)$ the nature of electronic spectra of all the complexes indicates an octahedral geometry around the central metal ions in the complexes. The electronic spectra of cobalt (II) complex have shows the $\mathrm{d}-\mathrm{d}$ transition bands at 9,546, 17325 and $21985 \mathrm{~cm}^{-1}$. These transitions may be assigned to the ${ }^{4} \mathrm{~T}_{1 \mathrm{~g}}(\mathrm{~F}) \rightarrow{ }^{4} \mathrm{~T}_{2 \mathrm{~g}}(\mathrm{~F}),{ }^{4} \mathrm{~T}_{1 \mathrm{~g}}(\mathrm{~F}) \rightarrow{ }^{4} \mathrm{~A}_{2 \mathrm{~g}}(\mathrm{~F})$ and ${ }^{4} \mathrm{~T}_{1 \mathrm{~g}}(\mathrm{~F})$ $\rightarrow{ }^{4} \mathrm{~T}_{1 \mathrm{~g}}(\mathrm{P})$ respectively. The spectra of nickel (II) complex have shows three $\mathrm{d}-\mathrm{d}$ transition bands at 11945 , 18,874 and $23923 \mathrm{~cm}^{-1}$. The transitions correspond to the ${ }^{3} \mathrm{~A}_{2 \mathrm{~g}}(\mathrm{~F}) \rightarrow{ }^{3} \mathrm{~T}_{2 \mathrm{~g}}(\mathrm{~F}),{ }^{3} \mathrm{~A}_{2 \mathrm{~g}}(\mathrm{~F}) \rightarrow{ }^{3} \mathrm{~T}_{1 \mathrm{~g}}(\mathrm{~F})$ and ${ }^{3} \mathrm{~A}_{2 \mathrm{~g}}(\mathrm{~F})$ $\rightarrow{ }^{3} \mathrm{~T}_{1 \mathrm{~g}}$ (P) respectively. The spectra of copper (II) complex have shows the d-d transition bands at 13534, 18874 and $25712 \mathrm{~cm}^{-1}$. These bands correspond to ${ }^{2} \mathrm{~A}_{1 \mathrm{~g}} \rightarrow{ }^{2} \mathrm{~B}_{1 \mathrm{~g}},{ }^{2} \mathrm{~B}_{2 \mathrm{~g}} \rightarrow{ }^{2} \mathrm{~B}_{1 \mathrm{~g}}$ and ${ }^{2} \mathrm{Eg} \rightarrow^{2} \mathrm{~B}_{1 \mathrm{~g}}$ transitions respectively. The complexes having six coordination number with octahedral geometry and $\mathrm{D}_{4} \mathrm{~h}$ symmetry. [23-24] .

3.3 Electron Spin Resonance: The ESR spectra of Co(II) \&Cu (II) complexes were recorded in nitrogen temperature, when the spectra were compared to that of room temperature in exhibiting all the hyperfine lines. The calculated parameter values are given in table .3 [25-26].

3.4 Mass spectra: : The mass spectra of the ferrocene based organometallic compound and its nickel complex were recorded show figure $4 \& 5$. The ferrocene based organometallic compound shows a molecular ion peak at $\mathrm{m} / \mathrm{z}$ 482.4. The molecular ion peak for the Nickel complex, observed at $\mathrm{m} / \mathrm{z} 561.03$ it is confirmed from its theoretical value. This composition is also supported by the mass spectra of other complexes. It is in good agreement with the micro analytical data [27-28].

3.5Antmicrobial Activity: The antimicrobial tests were performed by the standard disc diffusion method [29]. The complexes were screened for their antifungal activity against fungi viz. Aspergillus niger and Fusarium oxysporum. The cultures of the fungi were purified by single spore isolation technique. A concentration of 2 $\mathrm{mg} / \mathrm{cm}^{3}$ of each metal complex compound in DMF solution were prepared for testing against spore germination of each fungus. Filter paper discs of $10 \mathrm{~mm}$ in size, prepared by using Whatmann filter paper no. 41 were saturated with $5 \mu \mathrm{l}$ of the metal complex compounds dissolved in DMF solution or DMF as negative control. 
The fungal culture plates were inoculated and incubated at $25 \pm 20^{\circ} \mathrm{C}$ for $72 \mathrm{~h}$. The plates were then observed and the diameters of the inhibition zones (in $\mathrm{mm}$ ) were measured and tabulated. The antibacterial activity of the complexes was studied against Gram-positive bacteria Staphylococcus aureus and Gram-negative bacteria Escherichia coli. Each of the metal complex compounds dissolved in DMF at a concentration of $2 \mathrm{mg} / \mathrm{cm}^{3} \mathrm{was}$ prepared. Paper discs of Whatmann filter paper no. 41 were cut and sterilized in an autoclave. The paper discs were saturated with $5 \mu \mathrm{l}$ of the metal complex compounds dissolved in DMF solution or DMF as negative control and were placed aseptically in the Petri dishes containing Nutrient agar media inoculated with the above mentioned two bacteria separately. The petridishes were incubated at $370 \mathrm{C}$ and the inhibition zones were recorded after $24 \mathrm{~h}$ of incubation.

Antifungal activity the ferrocene based organometallic compound and their complexes were screened against E.Coli (bacteria Gram negative) S.Aureus (bacteria Gram positive) A.Nigar (fungus) F.oxysporum (fungus) and the values are given in Table 4. The complexes shows less activity as compare ferrocene based organometallic compound. However, ferrocene based organometallic compound ligand and their complexes showed lower activity as compared to standard drug. Antifungal activity studies of ferrocene based organometallic compound and its complexes against A.Nigar (fungus) F.oxysporum (fungus) shows that all the complexes are less activity than the ferrocene based organometallic compound. It is known that chelation tends to make the ferrocene based organometallic compound act as more powerful and potent antimicrobial agent, thus inhibiting more of the microbes than the parent ligand [30].

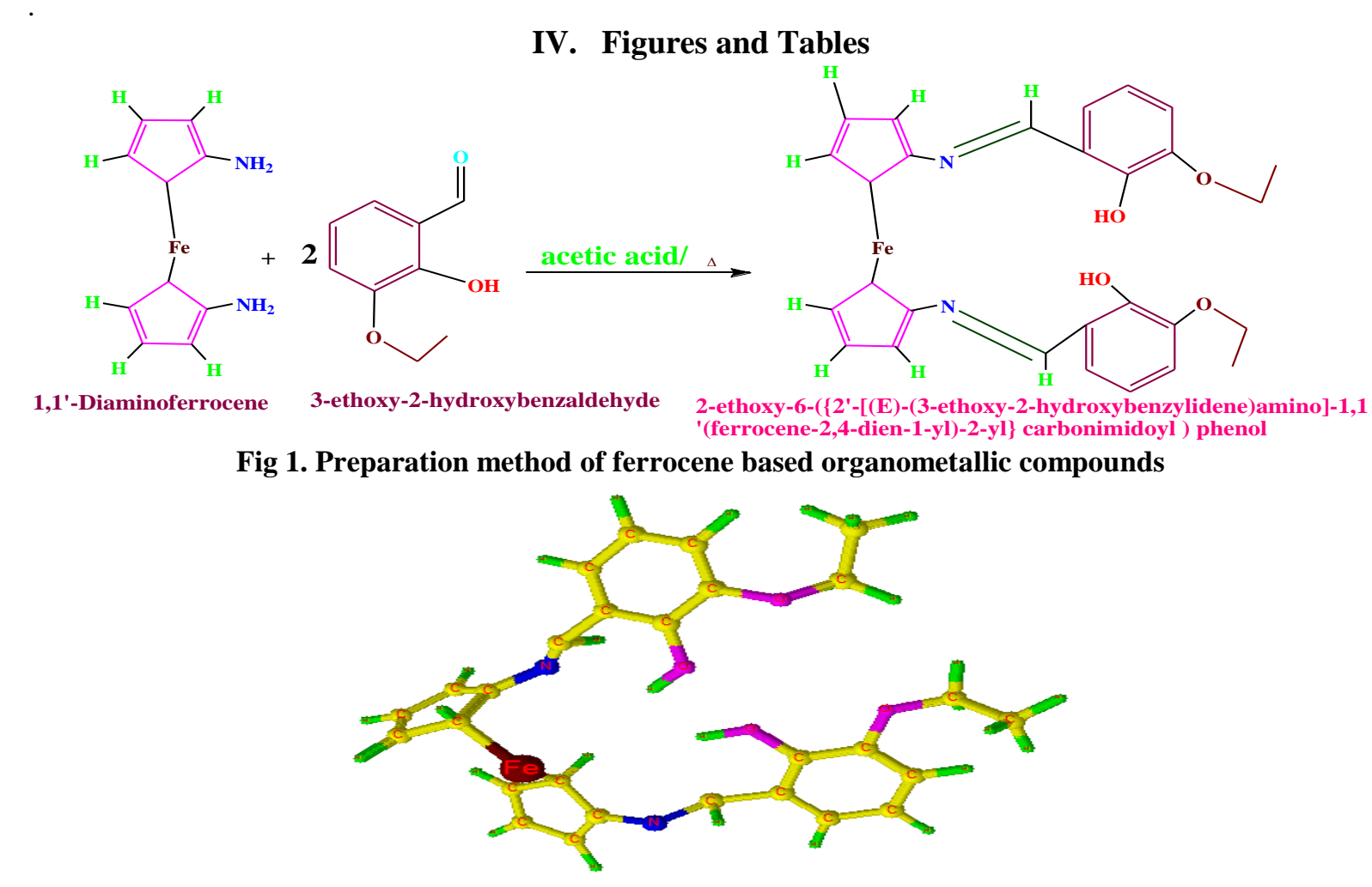

Figure 2 : 3D view of the prepared ferrocene based organometallic compound

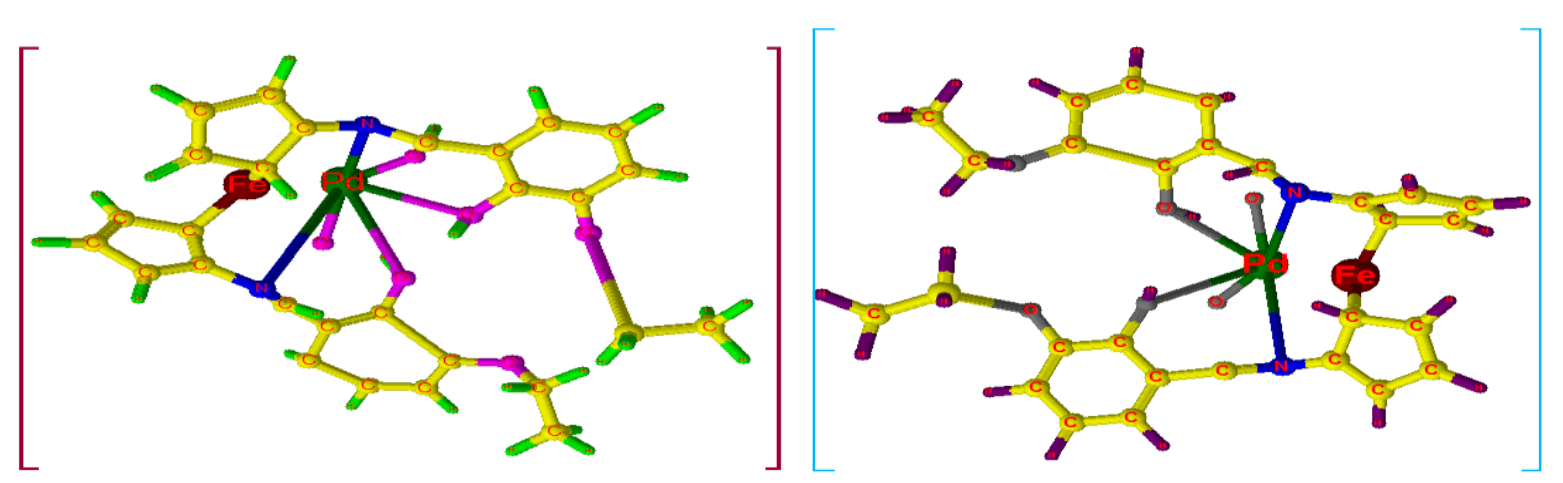

Figure 3: 3D view of the prepared Pd Complex of ferrocene based organometallic compound 
Synthesis of Ferrocene Based Organometallic Compounds \& Antimicrobial Activity

\begin{tabular}{|c|c|c|c|c|c|c|c|}
\hline & $\%$ yield & $\mathrm{MP} / \mathrm{DP}^{\circ} \mathrm{C}$ & $\mathrm{C} \%$ & $\mathrm{~N} \%$ & $\mathrm{Fe} \%$ & M\% & BM. $\mu$ eff \\
\hline$\left(\mathrm{C}_{26} \mathrm{H}_{24} \mathrm{~N}_{2} \mathrm{O}_{4} \mathrm{Fe}\right)$ & $71 \%$ & $235-238$ & $\begin{array}{l}64.84 \\
(64.52)\end{array}$ & $\begin{array}{l}5.78 \\
(5.58)\end{array}$ & $\begin{array}{l}11.53 \\
(11.25)\end{array}$ & & \\
\hline$\left[\mathrm{Mn}\left(\mathrm{C}_{26} \mathrm{H}_{22} \mathrm{~N}_{2} \mathrm{O}_{4} \mathrm{Fe}\right) \cdot 2 \mathrm{H}_{2} \mathrm{O}\right]$ & $52 \%$ & 199-201 & $\begin{array}{l}56.04 \\
(55.78)\end{array}$ & $\begin{array}{l}5.03 \\
(4.81)\end{array}$ & $\begin{array}{l}10.02 \\
(9.83)\end{array}$ & $\begin{array}{l}9.86 \\
(9.67)\end{array}$ & 5.45 \\
\hline$\left[\mathrm{Co}\left(\mathrm{C}_{26} \mathrm{H}_{22} \mathrm{~N}_{2} \mathrm{O}_{4} \mathrm{Fe}\right) \cdot 2 \mathrm{H}_{2} \mathrm{O}\right]$ & $54 \%$ & 192-194 & $\begin{array}{l}55.64 \\
(55.39)\end{array}$ & $\begin{array}{l}4.99 \\
(4.71)\end{array}$ & $\begin{array}{l}9.95 \\
(9.74)\end{array}$ & $\begin{array}{l}10.05 \\
(9.82)\end{array}$ & 4.49 \\
\hline$\left[\mathrm{Ni}\left(\mathrm{C}_{26} \mathrm{H}_{22} \mathrm{~N}_{2} \mathrm{O}_{4} \mathrm{Fe}\right) \cdot 2 \mathrm{H}_{2} \mathrm{O}\right]$ & $52 \%$ & $182-184$ & $\begin{array}{l}55.66 \\
(55.35)\end{array}$ & $\begin{array}{l}4.99 \\
(4.75)\end{array}$ & $\begin{array}{l}9.95 \\
(9.78)\end{array}$ & $\begin{array}{l}10.46 \\
(10.22)\end{array}$ & 3.25 \\
\hline$\left[\mathrm{Cu}\left(\mathrm{C}_{26} \mathrm{H}_{22} \mathrm{~N}_{2} \mathrm{O}_{4} \mathrm{Fe}\right) \cdot 2 \mathrm{H}_{2} \mathrm{O}\right]$ & $48 \%$ & $188-190$ & $\begin{array}{l}55.18 \\
(54.93)\end{array}$ & $\begin{array}{l}4.95 \\
(4.70)\end{array}$ & $\begin{array}{l}9.87 \\
(9.63)\end{array}$ & $\begin{array}{l}11.23 \\
(11.01)\end{array}$ & 1.85 \\
\hline$\left[\mathrm{Pd}\left(\mathrm{C}_{26} \mathrm{H}_{22} \mathrm{~N}_{2} \mathrm{O}_{4} \mathrm{Fe}\right) .2 \mathrm{H}_{2} \mathrm{O}\right]$ & $47 \%$ & $\begin{array}{l}177-179 \\
\end{array}$ & $\begin{array}{l}51.3 \\
(51.07)\end{array}$ & $\begin{array}{l}4.61 \\
(4.38)\end{array}$ & $\begin{array}{l}9.17 \\
(8.95)\end{array}$ & $\begin{array}{l}17.48 \\
(17.23)\end{array}$ & \\
\hline$\left[\mathrm{Pt}\left(\mathrm{C}_{26} \mathrm{H}_{22} \mathrm{~N}_{2} \mathrm{O}_{4} \mathrm{Fe}\right) \cdot 2 \mathrm{H}_{2} \mathrm{O}\right]$ & $44 \%$ & $172-174$ & $\begin{array}{l}44.78 \\
(44.53)\end{array}$ & $\begin{array}{l}4.02 \\
(3.83)\end{array}$ & $\begin{array}{l}8.01 \\
(7.84)\end{array}$ & $\begin{array}{l}27.97 \\
(27.71)\end{array}$ & \\
\hline
\end{tabular}

Table .1: Analytical data and Physical Data ferrocene based organometallic compound and Its Complexes

\begin{tabular}{|l|l|l|l|l|l|l|}
\hline Schiff base /Complexes & vC-OH & vC=N & vC-O & vM-N & vM-O & $2 \mathrm{H}_{2} \mathrm{O}$ \\
\hline$\left(\mathrm{C}_{26} \mathrm{H}_{24} \mathrm{~N}_{2} \mathrm{O}_{4} \mathrm{Fe}\right)$ & 3380 & 1690 & 1365 & - & - & - \\
\hline$\left[\mathrm{Mn}\left(\mathrm{C}_{26} \mathrm{H}_{22} \mathrm{~N}_{2} \mathrm{O}_{4} \mathrm{Fe}\right) \cdot 2 \mathrm{H}_{2} \mathrm{O}\right]$ & - & 1625 & 1322 & 559 & 417 & 3445,3538 \\
\hline$\left[\mathrm{Co}\left(\mathrm{C}_{26} \mathrm{H}_{22} \mathrm{~N}_{2} \mathrm{O}_{4} \mathrm{Fe}\right) \cdot 2 \mathrm{H}_{2} \mathrm{O}\right]$ & - & 1633 & 1318 & 568 & 435 & 3457,3522 \\
\hline$\left[\mathrm{Ni}\left(\mathrm{C}_{26} \mathrm{H}_{22} \mathrm{~N}_{2} \mathrm{O}_{4} \mathrm{Fe}\right) \cdot 2 \mathrm{H}_{2} \mathrm{O}\right]$ & - & 1622 & 1328 & 572 & 427 & 3438,3510 \\
\hline$\left[\mathrm{Cu}\left(\mathrm{C}_{26} \mathrm{H}_{22} \mathrm{~N}_{2} \mathrm{O}_{4} \mathrm{Fe}\right) \cdot 2 \mathrm{H}_{2} \mathrm{O}\right]$ & - & 1645 & 1333 & 560 & 445 & 3432,3522 \\
\hline$\left[\mathrm{Pd}\left(\mathrm{C}_{26} \mathrm{H}_{22} \mathrm{~N}_{2} \mathrm{O}_{4} \mathrm{Fe}\right) \cdot 2 \mathrm{H}_{2} \mathrm{O}\right]$ & - & 1635 & 1325 & 557 & 439 & 3435,3527 \\
\hline$\left[\mathrm{Pt}\left(\mathrm{C}_{26} \mathrm{H}_{22} \mathrm{~N}_{2} \mathrm{O}_{4} \mathrm{Fe}\right) \cdot 2 \mathrm{H}_{2} \mathrm{O}\right]$ & - & 1630 & 1331 & 563 & 412 & 3452,3507 \\
\hline
\end{tabular}

Table 2 : IR Spectral Data Of ferrocene based organometallic compound and Its Complexes in $\mathrm{Cm}^{-1}$

\begin{tabular}{|c|c|c|c|c|c|c|}
\hline complexes & $\mathbf{g}_{\text {II }}$ & $\mathbf{g}_{\mathbf{I}}$ & $\mathbf{g}_{\text {av }}$ & $\mathbf{G}$ & $\mathbf{A}_{\text {II }}$ & $\mathbf{A}_{\mathbf{I}}$ \\
\hline$\left[\mathbf{C o}\left(\mathbf{C}_{\mathbf{2 6}} \mathbf{H}_{\mathbf{2 2}} \mathbf{N}_{\mathbf{2}} \mathbf{O}_{\mathbf{4}} \mathbf{F e}\right)\right.$. 2 $\left.\mathbf{H}_{\mathbf{2}} \mathbf{O}\right]$ & 2.289 & 2.059 & 2.135 & 4.61 & 0.0137 & 0.0011 \\
\hline$\left[\mathbf{C u}\left(\mathbf{C}_{\mathbf{2 6}} \mathbf{H}_{\mathbf{2 2}} \mathbf{N}_{\mathbf{2}} \mathbf{O}_{\mathbf{4}} \mathbf{F e}\right) . \mathbf{2} \mathbf{H}_{\mathbf{2}} \mathbf{O}\right]$ & 2.295 & 2.065 & 2.142 & 4.47 & 0.0133 & 0.0014 \\
\hline
\end{tabular}

Table 3: Electron spin resonance spectral parameters

\begin{tabular}{|c|c|c|c|c|}
\hline \multicolumn{1}{|c|}{ sample } & \multicolumn{4}{|c|}{ Inhibition zone diameter(mm/mg Sample) } \\
\hline & E.Coli (bact.G-) & S.Aureus(bact. G+) & A.Nigar(fungus) & F.oxysporum(fungus) \\
\hline Control: DMF & 0.0 & 0.0 & 0.0 & 0.0 \\
\hline Tetracycline Antibacterial Agent(Std) & - & - & - & - \\
\hline Amphotericin B Antifungal agent & - & - & 15 & 17 \\
\hline$\left(\mathrm{C}_{26} \mathrm{H}_{24} \mathrm{~N}_{2} \mathrm{O}_{4} \mathrm{Fe}\right)$ & 24 & 27 & 10 & 11 \\
\hline$\left[\mathrm{Mn}\left(\mathrm{C}_{26} \mathrm{H}_{24} \mathrm{~N}_{2} \mathrm{O}_{4} \mathrm{Fe}\right) \cdot 2 \mathrm{H}_{2} \mathrm{O}\right]$ & 15 & 14 & 0.0 & 0.0 \\
\hline$\left[\mathrm{Co}\left(\mathrm{C}_{26} \mathrm{H}_{24} \mathrm{~N}_{2} \mathrm{O}_{4} \mathrm{Fe}\right) .2 \mathrm{H}_{2} \mathrm{O}\right]$ & 17 & 19 & 0.0 & 0.0 \\
\hline$\left[\mathrm{Ni}\left(\mathrm{C}_{26} \mathrm{H}_{24} \mathrm{~N}_{2} \mathrm{O}_{4} \mathrm{Fe}\right) \cdot 2 \mathrm{H}_{2} \mathrm{O}\right]$ & 12 & 11 & 0.0 & 0.0 \\
\hline$\left[\mathrm{Cu}\left(\mathrm{C}_{26} \mathrm{H}_{24} \mathrm{~N}_{2} \mathrm{O}_{4} \mathrm{Fe}\right) \cdot 2 \mathrm{H}_{2} \mathrm{O}\right]$ & 11 & 17 & 0.0 & 0.0 \\
\hline$\left[\mathrm{Pd}\left(\mathrm{C}_{26} \mathrm{H}_{24} \mathrm{~N}_{2} \mathrm{O}_{4} \mathrm{Fe}\right) \cdot 2 \mathrm{H}_{2} \mathrm{O}\right]$ & 20 & 19 & 05 & 06 \\
\hline$\left[\mathrm{Pt}\left(\mathrm{C}_{26} \mathrm{H}_{24} \mathrm{~N}_{2} \mathrm{O}_{4} \mathrm{Fe}\right) \cdot 2 \mathrm{H}_{2} \mathrm{O}\right]$ & 22 & 21 & 05 & 07 \\
\hline
\end{tabular}

Table : 4 Antimicrobial activity

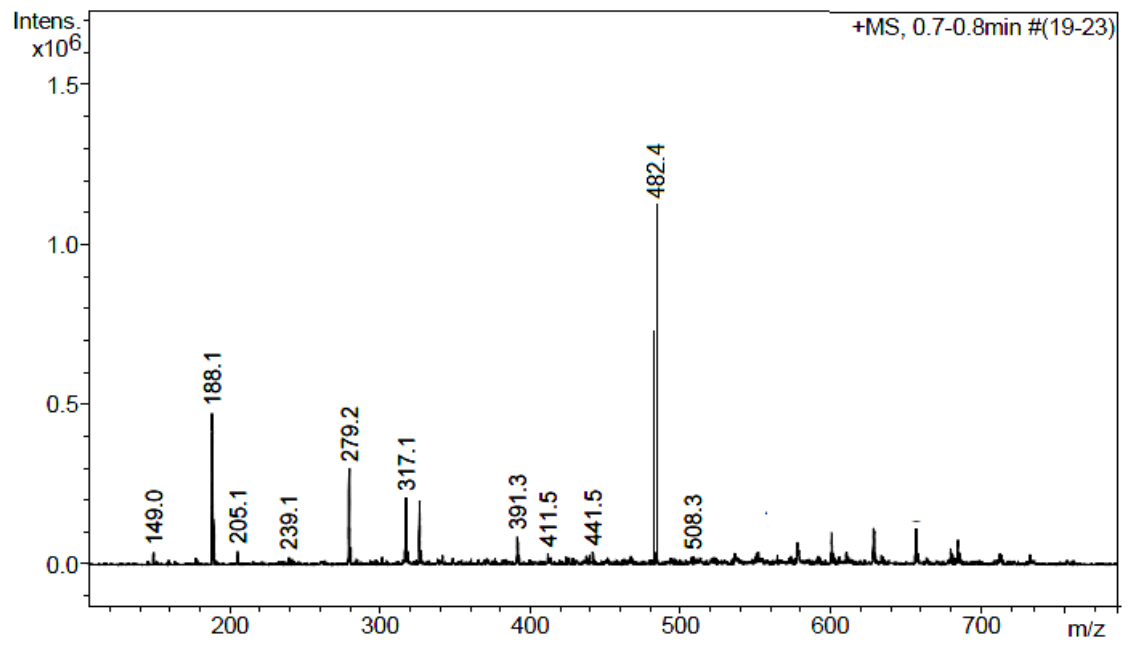

Fig: 4. Mass Spectral of ferrocene based organometallic compound $\left(\mathrm{C}_{26} \mathrm{H}_{24} \mathrm{~N}_{2} \mathrm{O}_{4} \mathrm{Fe}\right)$ 


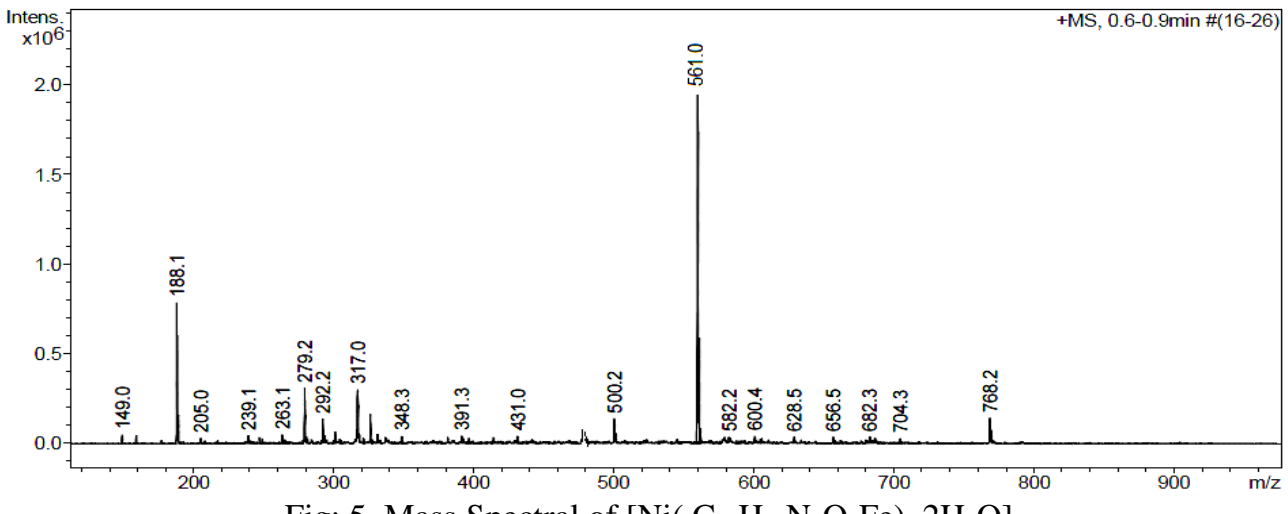

Fig: 5. Mass Spectral of $\left[\mathrm{Ni}\left(\mathrm{C}_{26} \mathrm{H}_{22} \mathrm{~N}_{2} \mathrm{O}_{4} \mathrm{Fe}\right) .2 \mathrm{H}_{2} \mathrm{O}\right]$

\section{Conclusion:}

The ferrocene based organometallic compound and its metal complexes of Mn-acetate, Co- acetate , $\mathrm{Ni}$ - acetate , $\mathrm{Cu}$ - acetate, $\mathrm{PdCl}_{2}$ and $\mathrm{PtCl}_{2}$ have been prepared and characterized on the basis elemental analysis, molar conductance, magnetic moment, infrared, electronic spectra, electron spin resonance, mass spectra and their microbial activity. The physical and analytical data show that the metal- ligand ratio of all complexes is 1:1. Complexes are non-electrolytes in nature, the ligand act as neutral and tetra coordinating through oxygen atoms of hydroxyl group, nitrogen atom of the azomethine group of 2-ethoxy-6-(\{2'-[(E)-(3-ethoxy-2hydroxybenzylidene)amino]-1,1'(ferrocene-2,4-dien-1-yl)-2-yl\} carbonimidoyl ) phenol. Complexes are octahedral geometry with coordination number six. The antimicrobial activity results indicate that, the metal complexes are less active as compared ferrocene based organometallic compound. We are proposed the following probable structure of the complex $\left[\mathrm{M}\left(\mathrm{C}_{26} \mathbf{H}_{22} \mathbf{N}_{2} \mathbf{O}_{4} \mathbf{F e}\right) .2 \mathbf{H}_{2} \mathbf{O}\right]$.

\section{Acknowledgement:}

Authors are thankful TIFR, IPCA and C-MET for providing necessary instrumental research facilities. Authors are also thankful for providing cooperation, help and moral support of Mayuri, Vishant and Lalita.

\section{References:}

[1] D.Csokas, B. Karolyi, S.Bosze, I.Szabo, G.Bati, L. Drahos and A. Csampai, 2,3-Dihydroimidazo[1,2- $b]$ ferroceno[ $d]$ pyridazines and a 3,4-dihydro- $2 H$-pyrimido[1,2-b]ferroceno $[d]$ pyridazine: Synthesis, structure and in vitro antiproliferation activity on selected human cancer cell lines, J. of Organometallic Chemistry, 750, 2014, 41-48

[2] M. Jonek, A. Makhloufi, W. Frank and C.Ganter, Synthesis and reactivity of (benz)imidazol-2-ylidenes with exocyclic $N$-acyl or $N$ sulfonyl groups, Journal of Organometallic Chemistry, 750, 2014,140-149.

[3] B. Sekhon, Inorganics/bioinorganics: Biological, medicinal and pharmaceutical uses, Journal of Pharmceutical Education and Research, 2( 1), 2011, 1-20.

[4] C.Hartinger, Applications of Metals in Medicine and Healthcare, Platinum Metals Review, 52(2), $2008,96$.

[5] C. Chitambar, Medical Applications and Toxicities of Gallium Compounds, Intrernational. J. Environment Research and Public Health, 7, 2010, 2337-2361

[6] M. Patra and G.Gasser, Organometallic compounds: an opportunity for chemical biology, ChemBioChem, 13(9),2012, $1232-52$.

[7] U.Dzhemilev, Metal Complex Catalysis in Organic and Organometallic Synthesis, Chemistry for Sustainable Development, $16,2008,621.632$

[8] H. Blaser, Adriano Indolese and Anita Schnyder Applied homogeneous catalysis by organometallic complexes, Current Science, 78(11), 2000, 1336-44

[9] J.Loch and R. Crabtree, Rapid screening and combinatorial methods in homogeneous organometallic catalysis, Pure and Applied Chemistry, 73(1), 2001,119-128.

[10] A.Gokcumen, G. Williams, D.Bregman, H.Pagano and E.Meggers, Organometallic Compounds with Biological Activity: A Very Selective and Highly Potent Cellular Inhibitor for Glycogen Synthase Kinase, ChemBioChem 7, 2006,443 - 1450.

[11] J.Bassett, R.Denney and G. Jeffery, Vogel's Textbook of Quantitative Inorganic Analysis, Longman: London, $5^{\text {th }}$ Ed., 2008.

[12] W.Geary, The use of conductivity measurements in organic solvents for the characterisation of coordination compounds, Coordination Chemistry Reviews, 7, 1971, 81-122.

[13] B. Kumar, V. Ravinder, G. Swamy and S.Swamy, Synthesis and characterization of iron(III), cobalt(II), nickel (II), copper(II), ruthenium(II, III), rhodium(III) and palladium(II) complexes with N-(2-carboxyphenyl)-and 2-amino-N-(2-carboxyphenyl)benzamides, Indian Journal of ChemistryA, 33,1994, 136-142.

[14] I.Asma, S.Amna, S.Mahmoud, A. Aref and F.Omar, Synthesis, Spectral and Thermal Studies on Cobalt(II),Copper(II), Nickel(II) and Zinc(II) Chelates with ptolylsalicylaldimine and Some Amino Acids, Synthetic Reactions in Inorg Met-Org Chem, 30(7),2000, 1373-92.

[15] K. Shankar, R. Roshni, K. Saravankumar, P.Reddy and Y. Peng, Synthesis of tetraaza macrocyclic Pd(II) complexes; antibacterial and catalytic studies, Journal of the Indian Chemical Society, 86(2),2009, 153-161.

[16] M. Nair and L. Sharma, Synthesis,spectral and thermal studies of $\mathrm{Cu}$ (II) complexes of azodyes derived from 2,3- dimethyl-1phenyl-4-amino-5-pyrazolone, Journal of the Indian Chemical Society, 86(2),2009, 133-138.

[17] V. Reddy, N. Patil and B. R. Patel, Synthesis and characterization of Co(II), Ni(II), and Cu(II) complexes with O,N and S donar ligands, Journal of Indian Council of Chemists, 23( 2),2006, 1-12. 
[19] T. Jeewoth , L. KamWah, M. Bhowon, G.Babooram, Synthesis and anti bacterial/Catalytic Properties of Schiff Bases and Schiff Base Metal Complexes derived from 2,3-Diaminopyridine, Synthetic Reaction Inorg Met-Org Chem, 30(6),2000, 1023-38.

[20] R. Maurya and S. Rajput, Oxovanadium(IV) complexes of bioinorganic and medicinal relevance: Synthesis, characterization and 3D molecular modeling and analysis of some oxovanadium(IV) complexes involving the $\mathrm{O}, \mathrm{N}$ donor environment of pyrazolonebased sulfa drug Schiff bases, Journal Molecular Structure,35, 2004, 687.

[21] D. Prakash, C. Kumar, S. Prakash, A. K. Gupta, and K. Singh, Synthesis, spectral characterization and antimicrobial studies of some new binuclear complexes of $\mathrm{Cu}$ (II) andNi( II )Schiff base, Journal of Indian Chemical Society, 86(12), 2009, 1257-1261.

[22] N. Raman, S. Esthar, and C. Thangaraja, A new Mannich base and its transition metal (II) complexes-synthesis, structural characterization and electrochemical study, Journal of Chemical Sciences, 116(4).2004, 209-213.

[23] K. Gudasi and T.Goudar, Synthesis and Characterization of Lanthanide(III) Complexes With salicylidene-2-Aminopyridine. Synthetic Reaction Inorg Metal-Organ Chem, 30(10), 2000, 1859-69.

[24] G. Hemakanthi, U. Balachandran and D.Aruna, Langmuir films of amphiphilic schiff base of $O$-Vaniline and its metal complexes. Chemical Physical Letter, 341(5-6), 2001, 407-11.

[25] I.Procter, B.Hathaway and P.Hodgson, The electronic properties and stereochemistry of the copper(II) ion: Mono (ethylene diamine) and mono(2,2-bipyridyl)-copper(II) complexes, Journal Inorganic Nuclear Chemistry, 34(12), 1972, 3689-97

[26] R.Giordano and R. Bereman, Stereoelectronic properties of metalloenzymes; Comparison of the coordination of copper (II) in galactose oxidase and a model system, $\mathrm{N}, \mathrm{N}^{\prime}$-ethylenebis(trifluoroacetylacetoniminato)copper(II). Journal of American Chemical Society, 96(4), 1974, 1019

[27] M. Khalil, E.Ismail, G. Mohamed, E. Zayed, and A. Badr, Synthesis and characterization of a novel Schiff base metal complexes and their applications, Open Journal of Inorganic Chemistry, 2, 2012, 13-21.

[28] S. Chandra, S. Parmar and Y. Kumar, Synthesis, spectroscopic and antimicrobial studies on bivalent zinc and mercury complexes of 2-formylpyridine thiosemicarbazone, Bioinorganic Chemistry and Applications, 6, 2006, 2009-18.

[29] M. Hania, Synthesis and antibacterial activity of some transition metal complexes of oxime, semicarbazone and phenylhydrazone, E-Journal of Chemistry, l( 6), 2009, 508-514.

[30] S. Biswas, T. Murugesan, K. Maiti, L. Ghosh, M. Pal and B. P. Saha, Study on the diuretic activity of Strychnos potatorum Linn. seed extract in albino rats, Phytomedicine, 89(6),2001, 469-471. 